\title{
Nutritional assessment of children at Nepal Medical College Teaching Hospital
}

\author{
P Rijal, A Sharma, S Shrestha and S Upadhyay \\ Department of Pediatric Medicine, Nepal Medical College Teaching Hospital \\ Kathmandu, Nepal
}

\begin{abstract}
Background: Child malnutrition is the single biggest contributor to under-five morbidity and mortality. Objectives: To assess the prevalence and types of malnutrition in children below 60 months of age, attending outpatient department at Nepal medical college teaching hospital in Attarkhel, Kathmandu, Nepal. Methods: A prospective study was carried out in five hundred and twelve children below 60 months of age from September 2010 to April 2011. Children detailed history, sex, weight were recorded and length/height were measured using standard technique. The length /height and weight were plotted on WHO centiles curves. ${ }^{1}$ The malnutrition were graded according to WHO classification. Result: Out of 512 children, according to WHO based on weight for age assessment, 148 (28.9\%) were undernourished .Subsequently, in weight for height analysis, 73 (14.2\%) were wasted and in height for age assessment, $64(12.5 \%)$ were stunted. The present study also shows , 59 (11.5\%), 50 (9.80\%) and $14(2.7 \%)$ children with acute, chronic and acute on chronic malnutrition. Conclusion: This study revealed that a high prevalence of undernutrition exists in Nepalese children. Overall, 28.9\% children were undernourished. Illiteracy, large family size, not exclusively breast feeding, delayed weaning and low socio- economic status are the major risk factors for malnutrition.
\end{abstract}

Keywords: anthropometry, undernutrition, World Health Organization.

\section{Introduction}

Under nutrition includes both protein energy malnutrition and micronutrient deficiencies. ${ }^{2}$ Undernourishment directly affects many aspects of the children's mental functions, growth and development which have adverse effects on children's ability to learn and process information and grow into adults. Undernourishment also impairs immune function leaving them more susceptible to infection. In any community, under- five children are one of the most vulnerable groups for nutritional deficiencies, owing to many factors ranging from

Address for correspondence

Dr Prashant Rijal

Department of Pediatric Medicine

Nepal Medical College, Kathmandu

Email: prasantrijal@hotmail.com low birth weight to maternal ill health to socioeconomic and environmental factor. ${ }^{3}$

Pre-school children, reflects the nutritional status of their community as a whole. ${ }^{4}$ The World Health Organization estimates that in year 2005, there were 126.5 million underweight and 147.5 million stunted pre-school children in the developing world that corresponds to $22.3 \%$ and $26.5 \%$ of their total population in developing countries respectively. South East Asian region has more pathetic situation with $23.4 \%$ children underweight and $22.7 \%$ being stunted. ${ }^{5}$ The 2006 Nepal demographic and health survey (NDHS) found $45 \%$ and $43 \%$ of children below the age of five years to be underweight and stunted, respectively.

Nutritional status of our country is very poor. Hence, this study was done to know the prevalence and types of malnutrition in children. 


\section{Methods}

To estimate the prevalence and types of malnutrition, a prospective study was conducted in 512 children below 60 months of age attending out-patient department at Nepal medical college teaching hospital, Attarkhel, Kathmandu, Nepal from September, 2010 to April 2011.The consent was taken from all the parents before the assessment. Systemic random sampling was done for selection of the children. The children with chronic diseases, diarrhea with dehydration, acute illness of more than 2 days, genetic diseases, gross congenital malformation and more than 5 years of age were excluded from this study. The detail studies was done by accumulating the information regarding address, feeding pattern ( breast feeding, bottle feeding, weaning), status of parents (alive or not), occupation, income, education, family size, water and disposal system. Body weight was recorded to the nearest $0.1 \mathrm{~kg}$ using a balance beam scale . The body length in children less than 24 months were measured nearest to $0.5 \mathrm{~cm}$ by standard technique using infantometer in recumbent position and the height in older children nearest to $0.5 \mathrm{~cm}$ on the stadiometer. Nutritional status and protein energy malnutrition were expressed by weight for age, weight for height for age classification of WHO. ${ }^{6}$ The standards used being WHO $50^{\text {th }}$ percentiles growth chart.

\section{Results}

In this study, 512 children were enrolled. Males and females were 291(56.8\%) and 221(43.2\%) respectively. WHO base on weight for age assessment shows, 148 (28.9\%) were undernourished. Eightyseven $(17.0 \%)$ male and 61 $(11.9 \%)$ were female shown in Table-1.

\section{Table 1: Distribution of children according to WHO Classification}

\begin{tabular}{|l|l|l|l|l|}
\hline \multirow{2}{*}{ Wt.for age } & \multicolumn{2}{|c|}{ No. of children } & \multirow{2}{*}{ Total } & \multirow{2}{*}{ Reference } \\
\cline { 2 - 3 } & Male & \multicolumn{1}{|l}{ Female } & & \\
\hline \multirow{3}{*}{$>80 \%$} & $291(56.8 \%)$ & $221(43.2 \%)$ & 512 & \\
$60-80 \%$ & $204(39.8 \%)$ & $160(31.2 \%)$ & & Normal \\
$<60 \%$ without edema & $83(16.2 \%)$ & $58(11.3 \%)$ & $141(27.5 \%)$ & Undernutrition \\
& $4(0.8 \%)$ & $3(0.7 \%)$ & $7(1.4 \%)$ & Marasmus \\
& $87(17.0 \%)$ & $61(11.9 \%)$ & $148(28.9 \%)$ & Total undernutrition \\
\hline
\end{tabular}

In weight for height analysis, 53 (10.3\%) children were wasted and $20(3.9 \%)$ were severely wasted. Total, $43(8.4 \%)$ male and $30(5.8 \%)$ female children were moderately to severely wasted shown in Table- 2.

Table 2: Distribution of children according to WHO Classification

\begin{tabular}{|c|c|c|c|c|}
\hline \multirow{2}{*}{$\begin{array}{l}\text { Wt.for Ht. } \\
\text { (wasting measuring) }\end{array}$} & \multicolumn{2}{|c|}{ No. of Children } & \multirow[t]{2}{*}{ Total } & \multirow[t]{2}{*}{ Reference } \\
\hline & Male & Female & & \\
\hline & $291(56.8 \%)$ & $221(43.2 \%)$ & & \\
\hline$>80 \%$ & $248(48.4 \%)$ & $191(37.3 \%)$ & $439(85.7 \%)$ & Normal \\
\hline $70-79 \%(-2$ to-3SD) & $32(6.2 \%)$ & $21(4.1 \%)$ & $53(10.3 \%)$ & Moderate \\
\hline$<70 \%(<-3 \mathrm{SD})$ & $11(2.1 \%)$ & $9(1.7 \%)$ & $20(3.9 \%)$ & $\begin{array}{l}\text { Undernutrition (wasting) } \\
\text { Severe Undernutrition } \\
\text { (Severe wasting) }\end{array}$ \\
\hline $\begin{array}{l}\text { Total moderate to } \\
\text { severe wasting }\end{array}$ & $43(8.4 \%)$ & $30(5.8 \%)$ & $73(14.2 \%)$ & \\
\hline
\end{tabular}

Lastly, in height for age assessment, $51(10.0 \%)$ children were stunted and $13(2.5 \%)$ was severely stunted.Total, $36(7.0 \%)$ male and $28(5.5 \%)$ female children were moderately to severely stunted shown in Table-3. 
Table 3: Distribution of children according to WHO Classification

\begin{tabular}{|l|l|l|l|l|}
\hline \multirow{2}{*}{$\begin{array}{l}\text { Ht.for age } \\
\text { (stunting measuring) }\end{array}$} & \multicolumn{2}{|c|}{ No. of Children } & Total \% & Reference \\
\cline { 2 - 3 } & Male & \multicolumn{2}{|c|}{ Female } & \\
ed90\% & $291(56.8 \%)$ & $221(43.2 \%)$ & 512 & \\
$85-89 \%(-2$ to-3SD) & $255(49.8 \%)$ & $193(37.7 \%)$ & $448(87.5 \%)$ & Normal \\
& $29(5.7 \%)$ & $22(4.3 \%)$ & $51(10.9 \%)$ & $\begin{array}{l}\text { Moderate Under-nutrition } \\
\text { (stunting) }\end{array}$ \\
$<85 \%(<-3 \mathrm{SD})$ & $7(1.4 \%)$ & $6(1.2 \%)$ & $13(2.5 \%)$ & $\begin{array}{l}\text { Severe Undernutrition } \\
\text { (Severe stunting) }\end{array}$ \\
$\begin{array}{l}\text { Total moderate to } \\
\text { severe stunting }\end{array}$ & $36(7.0 \%)$ & $28(5.5 \%)$ & $64(12.5 \%)$ & \\
\hline
\end{tabular}

Subsequently, according to WHO, 59 (11.5\%), 50 (9.8\%), and 14 (2.7\%) children had acute, chronic and acute on chronic malnutrition shown in Table-4.

Table 4: Detection of chronic, acute and acute on chronic malnutrition according to WHO

\begin{tabular}{|l|l|l|l|l|l|}
\hline \multirow{2}{*}{ Wt.for Ht. } & \multirow{2}{*}{ Ht.for age } & \multicolumn{2}{|c|}{ No. of Children } & \multirow{2}{*}{ Total } & Reference \\
\cline { 3 - 4 } & & Male & Female & & \\
\hline & & $291(56.8 \%)$ & $67(43.2 \%)$ & 155 & \\
ed $80 \%$ & ed90\% & $221(43.7 \%)$ & $168(32.8 \%)$ & $389(75.9 \%)$ & Normal \\
$<80 \%$ & ed90\% & $34(6.6 \%)$ & $25(4.9 \%)$ & $59(11.5 \%)$ & Wasted \\
ed $80 \%$ & dd90\% & $27(5.3 \%)$ & $23(4.5 \%)$ & $50(9.8 \%)$ & Stunted \\
$<80 \%$ & $<90 \%$ & $9(1.7 \%)$ & $5(0.9 \%)$ & $14(2.7 \%)$ & Wasted and Stunted \\
\hline
\end{tabular}

The highest number of malnourished children were 42 (42.8\%) in $13-24$ months and lowest were 12 $(16.9 \%)$ in $7-12$ months age group shown in Table-5.

Table 5: Distribution of children according to age

\begin{tabular}{|l|c|c|c|c|c|c|}
\hline $\begin{array}{l}\text { Nutrition } \\
\text { status }\end{array}$ & $<6 \mathrm{mth}$ & $7-12 \mathrm{mth}$ & $13-24 \mathrm{mth}$ & $25-36 \mathrm{mth}$ & $37-48 \mathrm{mth}$ & $49-60 \mathrm{mth}$ \\
\cline { 2 - 7 } & $\mathrm{n}$ & $\mathrm{n}$ & $\mathrm{n}$ & $\mathrm{n}$ & $\mathrm{n}$ & $\mathrm{n}$ \\
\hline $\begin{array}{l}\text { Normal } \\
\text { nutrition }\end{array}$ & $63(12.3 \%)$ & $71(13.9 \%)$ & $98(19.1 \%)$ & $104(20.3 \%)$ & $92(17.9 \%)$ & $84(16.4 \%)$ \\
$\begin{array}{l}\text { Malnutrit- } \\
\text { ion }\end{array}$ & $15(22.2 \%)$ & $12(16.9 \%)$ & $42(42.8 \%)$ & $38(36.5 \%)$ & $19(20.6 \%)$ & $23(27.4 \%)$ \\
\hline
\end{tabular}

Here, five known factors for malnutrition were considered. It has been observed that extent of malnutrition was significantly high in children around $53.9 \%$ and $40.6 \%$ in illiterate mothers and fathers. It also shows, $71.6 \%$ of children with large family size suffer more from malnutrition. Children who are not exclusively breast feeding and delayed weaning, subsequently had $37.4 \%$ and $44.0 \%$ of malnutrition shown in Table- 6 . 
Table 6: Distribution of children according to sex, literacy of parents, family size, weaning, breast feeding

\begin{tabular}{|l|c|c|}
\hline Study variables & $\begin{array}{c}\text { Total no. of childrens } \\
\text { No.(512) }\end{array}$ & $\begin{array}{c}\text { Children suffering from malnutrition } \\
\text { WHO weight for age }\end{array}$ \\
\cline { 3 - 3 } & & n \\
\hline Sex & $291(56.8 \%)$ & $87(17.0 \%)$ \\
Male & $221(43.2 \%)$ & $61(11.9 \%)$ \\
Female & & \\
Mother's literacy & $299(58.4 \%)$ & $33(11.0 \%)$ \\
literate & $213(41.6 \%)$ & $115(53.9 \%)$ \\
illiterate & & \\
Father's literacy & $347(67.8 \%)$ & $81(23.4 \%)$ \\
literate & $165(32.2 \%)$ & $67(40.6 \%)$ \\
illiterate & & $38(15.6 \%)$ \\
Size of family & $244(47.6 \%)$ & $54(28.9 \%)$ \\
Small ( dd 2 children) & $187(36.5 \%)$ & $58(71.6 \%)$ \\
Medium (3-4) & $81(15.8 \%)$ & $36(17.1 \%)$ \\
Large (>4 children) & & $85(44.0 \%)$ \\
Age of weaning & $210(41.0 \%)$ & $27(24.8 \%)$ \\
$<6$ mths & $193(37.7 \%)$ & \\
$>6$ 6mths & $109(21.2 \%)$ & \\
yet to wean & & $107(37.4 \%)$ \\
Duration of exclusive breast feeding (EBF) & & \\
breast feeding & & \\
(4-6 mths) & $226(44.1 \%)$ & \\
not EBF & $286(55.8 \%)$ & \\
\hline
\end{tabular}

The children from parents of low socio- economic status had high risk of malnutrition shown in Table-7.

Table 7: Distribution of children according to socio- economic status

\begin{tabular}{|l|c|c|c|c|c|}
\hline \multirow{2}{*}{ Nutritional status } & \multirow{2}{*}{ Upper } & \multicolumn{2}{|c|}{ Middle } & \multicolumn{2}{c|}{ Lower } \\
\cline { 3 - 6 } & & upper middle & lower middle & upper lower & lower \\
\hline Normal nutrition & $4(0.8 \%)$ & $22(4.3 \%)$ & $43(8.4 \%)$ & $176(34.3 \%)$ & $267(52.1 \%)$ \\
malnutrition & - & $3(13.6 \%)$ & $8(18.6 \%)$ & $48(27.3 \%)$ & $89(33.3 \%)$ \\
\hline
\end{tabular}

\section{Discussion}

Anthropometric indices are used as the main criteria for assessing the nutritional status of children by comparing them to a reference growth chart. Deficits in the anthropometric indices from the median value of the population are regarded as evidence of malnutrition. In children, the 3 most commonly used anthropometric indices are weightfor-height, height-for-age, and weight-for-age. Deficit in height-for-age is called stunting or shortness and indicates chronic malnutrition. Deficit in weight-for-height is called wasting and indicates acute malnutrition. Deficit in weight-for-age is often referred to as underweight and reflects low weightfor-height, low height-for-age, or both (global malnutrition). Weight-for-age is thus not a good indication of recent nutritional stress in the population. ${ }^{7}$ In our study, WHO based on weight for age shows, $28.9 \%$ children were undernourished. A study done by Masood shows, $53.8 \%$ of children had malnutrition which was more as compare to our study. ${ }^{89}$ Statistically, there was a slightly higher gender 
difference, around $17.0 \%$ male and $11.9 \%$ female were undernourished. Similar study done by Bhalani shows, higher prevalence of malnutrition in girls around $28.4 \%$ as against $16.9 \%$ in boys. ${ }^{10} \mathrm{WHO}$ anthropometric system also helps to identify $11.5 \%$ children with acute, $9.8 \%$ children with chronic and $2.7 \%$ with acute on chronic malnutrition. If IAP guidelines were followed, then we would have missed the wasted and stunted children. ${ }^{11}$ Education of mothers and fathers has significant effect on the nutritional status of their children. Here, 213 (41.6\%) mothers and $165(32.2 \%)$ fathers were illiterate out of which $115(53.9 \%)$ and $67(40.6 \%)$ children had malnutrition. This study shows that, $58(71.6 \%)$ children from larger family suffer more from malnutrition compare to small family where only $19.6 \%$ of children had malnutrition. Two hundred and eighty six (55.8\%) children were not exclusively breast fed in which 107 (37.4\%) had more malnutrition in contrast to exclusively breast fed children. Delayed weaning is highly associated with malnutrition in 85 (44\%) children. Similar study was done by Mallik et al shows $60.0 \%, 61.1 \%, 66.7 \%$ and $100 \%$ children were malnourished because of illiterate mother, large family size, delayed weaning and not exclusively breast feeding. ${ }^{12}$

The effect of low socio-economic status is also one of the major risk factor for malnutrition. Here, 48 $(27.3 \%)$ and 89 (33.3\%) children with upper lower and lower socio-economic status had malnutrition. ${ }^{13}$

\section{Conclusion}

Overall, $28.9 \%$ children were malnourished. This is a serious problem, by any scale. More wide spread use of WHO score system of classification, especially in community-based studies, is recommended. The finding of this study confirmed that lack of formal education, large family size, late weaning, lack of breast feeding, low socio-economic status were the risk factors that were associated with malnutrition in children.We should make a comprehensive, integrated and intersectoral strategy for addressing under-nutrition. The nutritional assessment and gap analysis is necessary for better implementation.

\section{References}

1. Silveira FJ, Lamounier JA. Nutritional assessment of children of the Jequitinhonha valley region in Brazil with NCHS and the new
WHO growth charts. Rev Paul Pediatr 2009; 27 (2) : 133- 38.

2. Maharaj KB, Halvor S, Tor S. Micronutrient deficiency in children. British J Nutr 2001; 85 (suppl 2): 199 - 203.

3. Chandra RK. Nutrition and Immunology: from the clinic to cellular biology and back again. Proc Nutr Soc1999; 58 (3): 681-3.

4. Gupta BM, Bhandari B. Nutritional assessment of rural pre-school children. Indian J Pediatr 1973; 40: 142.

5. De Onis M, Blossner M, Borghi E, Morris R, Frongillo EA. Methodology for estimating regional global trends of child malnutrition. Int $J$ Epidem 2004; 33 (6): 1260-70.

6. Ghai OP, Gupta P, Paul VK. Protein energy malnutrition. In: Gupta P, Shah D editors. Ghai essential Pediatrics 6 ${ }^{\text {th }}$ edition. 2005: $101-18$.

7. Sampson A. Malnutrition: Missed opportunities for diagnosis. Ghana Med J 2008; 42 (3): 101-104.

8. Masood-us- syed SS, Muhammd S, Butt ZK. Nutritional assessment of children under the age of sixty months in district Sialkot, Pakistan. $J$ Pak Med St 2011;1:7-12.

9. Deshmukh PR, Dongre AR, Gupta SS, Garg BS. Newly develop WHO growth standards: implication for demographic surveys and child health programs. Indian J Pediar 2007;74(11): 987-90.

10. Bhalani KD, Kotecha PV. Nutritional status and gender differences in the children of less than 5 years of age attending ICDS Anganwadis in Vadora city. Indian J Community Med 2002; 27 : 3.

11. Li Y, Guo G, Shi A et al. Prevalence and correlates of malnutrition among children in rural minority areas of China. Pediatr Int 1999; 41: 549.

12. Mallik S, Mitra SP, Roy A, Basu SS, Saha A, Munsi AK. Malnutrition - a missed opportunity to treat at tertiary care. Indian J community Med 2006;31 (3):196.

13. Ahmed AE, ZM Elkady, Hussein AA, Abdrbou AA. Risk factors of protein energy malnutrition “ kwashiorkor and marasmus" among children under five years of age in Assiut university children hospital. J American scien 2011; 7 (4): 592-604.

14. Seal AJ, Kerac M. Operational implications of using 2006 World Health Organization growth standards in nutritional programmes: Secondary data analysis. BMJ 2007; 334:733. 